\title{
NOTE
}

\section{THE JUDICIAL INTERPRETATION OF SUICIDE *}

Judicial assumptions about the nature and frequency of suicide underly a number of evidentiary and substantive rules, but the reported opinions indicate that only rarely have these assumptions been derived from a thorough and informed examination of the subject. The casualness of the judicial approach to suicide is paralleled by the subject's neglect in scientific literature. ${ }^{1}$ While statistical studies of suicide ${ }^{2}$ have interested numerous writers, particularly life insurance authorities, ${ }^{3}$ neither the actuaries nor the sociologists have formulated comprehensive and systematic hypotheses as to the causes of suicide. ${ }^{4}$ The chief advances in the knowledge of suicide have come through the psychoanalysts. ${ }^{5}$ Even they, however, have studied the intention to commit suicide much more than the act itself. ${ }^{6}$ Notwithstanding such limitations, it is submitted that legal assumptions about suicide may be made sounder by critical reference to the existing studies.

Accordingly, this Note will examine, in the light of sociological and psychoanalytic findings, four situations in which judicial assumptions about

* Based on materials from Levin, Evidence and the BeHavioral ScIENCES (mimeo. 1956). These materials were prepared with the participation of the following consultants from a project on $\mathrm{Law}$ and Behavioral Science of which evidence is one phase, being conducted at the University of Pennsylvania Law School under a grant from the National Institute of Mental Health: Andrew S. Watson, M.D. (project co-director); M. E. Bitterman, Ph.D.; Richard G. Longsdorf, M.D.; Julius Wishner, $\mathrm{Ph} . \mathrm{D}$.; Marvin E. Wolfgang, Ph.D.

1. See Menninger, MaN Against Himself 13 (1938) (hereinafter cited as MENNINGER), where the limited extent of study is offered as evidence of a taboo associated with the subject. See also Simpson, Introduction to DURKHEIM, SUICDE (1951).

2. Such studies are admittedly subject to a large element of error due to the unreliability of available primary data, since all too many suicides are not reported as such. Those who kill themselves through automobile accidents are almost never recorded as suicides; those who sustain serious injuries and die weeks or months later are rarely registered as suicides; a great many suicides are concealed by families, and suicidal attempts, no matter how serious, are even less likely to find their way into tables of vital statistics. Zilboorg, Sticide Among Civilized and Primitive Races, 92 AM. J. Psych. (1936) ; Dublin, The Facts of LmE, 259 (1951).

3. See, e.g., id. at 259-65. For a compendium of actuarial works, see BuNzEr, To $\mathrm{BE}$ OR NO' TO $\mathrm{BE}$ (1933).

4. The actuaries have studied the overall extent and trends of suicide, and related it to race and color incidence, age and sex distribution, urban and rural areas, seasonality, economic conditions, religious affiliations, marital status and method. See, e.g., Dublin, op. cit. supra note 2; Schmid \& Van Arsdol, Completed and Attempted Suicides: A Comparative Analysis, 20 AM. Soc. REv. 273 (1955). note 1 .

5. This seems to be acknowledged even by the sociologists. $C f$. Simpson, supra

6. MENNINGER 16. Suicide is an extremely infrequent event, and very few of those patients who express suicide thoughts actually commit suicide. Rosen, Detection of Suicidal Patients: An Example of Some Limitations in the Prediction of Infrequent Everts, 18 J. Consult. Psych. 397 (1954). 
suicide are crucial: First, where the prosecution in a criminal trial offers evidence of the accused's attempted suicide to show that he was conscious of his guilt or that he desired to escape deserved punishment. Second, where a homicide defendant, in an effort to prove that the alleged victim committed suicide, presents evidence that the deceased had under previous circumstances threatened suicide. Third, where the defendant in a criminal trial attempts to introduce as exculpating evidence statements contained in the suicide note of a third person; or where the prosecution seeks to introduce a third person's suicide note to inculpate the defendant. Finally, where the petitioner in a workmen's compensation proceeding seeks to prove that physical injuries in the course of employment proximately caused the worker's subsequent suicide.

No illusions should be entertained as to the conclusiveness of much of the data here presented. The psychoanalytic findings, in particular, have not been thoroughly tested by empirical, experimental or semi-experimental investigations. ${ }^{7}$ However, it should be emphasized that the views reflected in this data receive support from all psychiatric schools. An extensive investigation of the literature indicates that the vast majority of psychiatrists -Freudian, neo-Freudian or anti-Freudian-who attempt a dynamic understanding of the individual, substantially agree with these interpretations of suicide motivations. ${ }^{8}$

\section{Admissibility of Evidence of the Attempted Suicide OF THE ACCUSED}

Where the accused in a criminal case attempts suicide between the time of the alleged crime and the trial, the prosecution may be anxious to have this conduct admitted as evidence against the defendant. Whether the prosecution may do so has been at issue in the reported opinions of at least nine jurisdictions. ${ }^{9}$ In these cases, virtually all of the defendants were, at the time of their suicide attempts, in confinement awaiting trials for murder. ${ }^{10}$ Evidence of the attempt was uniformly admitted and doubt-

7. It has been suggested that this is because until recent years experimental techniques were not sufficiently developed to study the kinds of behavior to which Freud applied himself. SEARS, SURVEY OF ORJECTIVE STUDIES OF PSYCHOANALYTIC CONCEPTS ix (1943). Nevertheless, in some instances Freud's views have been supported and his principles significantly extended. See, e.g., id. at 81-94, 137-39, on fixation and regression, a process referred to in text at notes $23-24$ infra. In other instances objective techniques appear to have cast doubt on Freudian views. See, e.g., Orlansky, Infant Care \& Personality, 46 PSYCH. BuLL. 1 (1949), on the effect of certain features of infant care upon personality.

8. LeVin, EVIDENCE AND THE BeHavioral SciENCES C-8 (mimeo. 1956).

9. State v. Hargraves, 62 Idaho 8, 107 P.2d 854 (1940) ; State v. Bittner, 209 Iowa 109,227 N.W. 601 (1929); Commonwealth v. Goldenberg, 315 Mass. 26, 51 N.E.2d 762 (1943) ; State v. Painter, 329 Mo. 314, 44 S.W.2d 79 (1931); State v. Plunkett, 62 Nev. 265, 149 P.2d 101 (1944) ; State v. Jaggets, 71 N.J.L. 281, 58 Ati. 1014 (1904); State v. Blancett, 24 N.M. 433, 174 Pac. 207 (1918); State v. Marsh, 234 N.C. 101, 66 S.E.2d 684 (1951) ; State v. Exum, 213 N.C. 16, 195 S.E. 7 (1939) ; State v. Lawrence, 196 N.C. 562, 146 S.E. 395 (1929); Commonwealth v. Giacobbe, 341 Pa. 187, 19 A.2d 71 (1941).

10. The defendants in State v. Plunkett, supra note 9 and Commonwealth v. Giacobbe, supra note 9, were execeptions. 
less considered by the jury in finding the defendants guilty. ${ }^{11}$ On appeal defendants averred such admission to be erroneous, generally relying on State $v$. Coudotte. ${ }^{12}$ There the prosecution's case rested upon the testimony of two confessed accomplices. By statute such evidence would not support a conviction without corroborating evidence tending to connect defendant with the commission of the offense. The court, holding that evidence of the attempted suicide did not constitute sufficient corroboration, did not pass upon its admissibility generally. Restricting the Coudotte case to this narrow holding and analogizing evidence of suicide to that of flight, which is admissible as tending to show consciousness of guilt and a desire to escape punishment, the appellate courts in each jurisdiction in which the question has arisen have held evidence of attempted suicide properly admitted.

An opposite view was advanced almost thirty years ago ${ }^{13}$ by the now Dean Fordham, suggesting that such evidence generally is not logically relevant and should therefore be excluded. $\mathrm{He}$ pointed out that relevance premises that an accused who attempts suicide is more likely to be guilty than one who does not attempt suicide. ${ }^{14}$ This premise might have been demonstrated by statistics showing that a larger ratio of accused persons who attempt suicide are guilty than of those who do not attempt it. However, no such statistics were available. This premise might also have been demonstrated by a determination that the dominant motive underlying attempted suicide in this situation is consciousness of guilt or a desire to escape deserved punishment, ${ }^{15}$ rather than any of numerous other motives. However, since ordinary human experience in such matters was too limited to indicate which motive was in fact dominant, and the paucity of learned literature on suicidal behavior rendered impossible at that time any expert appraisal of the question, it was concluded that the evidence could not properly be admitted. More complete expert understanding of the subject today dictates the same conclusion, notwithstanding an unbroken line of legal authority to the contrary.

The immediate causes of suicide are probably as numerous and varied as the number of people who commit the act. The layman is accustomed to recognizing hardships of various kinds, such as loss of employment, physical injury, ill health, loss of status or love as triggering self-destruction. ${ }^{16}$ However, it is perhaps less willingly recognized that a characteristic

11. Since the state seldom may, and rarely does, appeal an acquittal, the reports do not contain cases in which attempted suicide by the accused was in evidence and a verdict of acquittal was rendered.

12. 7 N.D. 109, 72 N.W. 913 (1897).

13. Note, 7 N.C.L. Rev. 290 (1929).

14. Cf. Trautman, Logical or Legal Relevancy, 5 VAND. L. Rev. 385, 388 (1952): "Fact $A$ will be said to be logically relevant to fact $B$ when, according to human experience, it is so related to fact $B$ that fact $A$, considered either by itself or in connection with other facts, renders probable the past or future existence or non-existence of fact B."

15. Cf. MCCoRMICK, EVIDENCE 318-19 (1954) (hereinafter cited as McCoRMrcK) (discussing attempted suicide during confinement awaiting trial for murder).

16. See, e.g., 14 Encyclopedia of the Social ScIences, Suicide 456, 458 (1937). 
of many suicides is the apparent inadequacy of the precipitating event. ${ }^{17}$ For example, a girl killed herself, having become depressed after bobbing her hair; a man killed himself, having been forced to quit playing golf; a woman committed suicide after missing two trains; a boy took his life when his pet canary died. ${ }^{18}$ The list could be extended almost indefinitely. Moreover, most laymen would probably resist the suggestion that suicidally-disposed personalities react suicidally not only to hardship but also to good fortune. Both psychological ${ }^{19}$ and sociological ${ }^{20}$ studies, however, have established that suicide frequently immediately follows an increase in income, a promotion or a sudden self-realization of importance and prestige.

To understand how apparently inadequate events may precipitate suicide, one must look beyond the events immediately preceding the act. The psychiatrist classically attributes suicide in Western culture ${ }^{21}$ to the operation of long-developed aggressive and guilt feelings in an emotionally immature person. ${ }^{22}$ More specifically, it is regarded as based characteristically on an individual's fixation to infantile behavior patterns, ${ }^{23}$ including a tendency to react to frustration with violence and to fulfill desires by ingratiation and submissiveness. ${ }^{24}$ It might be expected that because of his exaggerated reaction to frustration, the classic suicidal type would respond to threats to his self-esteem with the feeling that he is no longer respected or even that he is hated. However, it is characteristic of such an individual's immature state that his self-esteem is completely regulated by the approval or disapproval of other people ${ }^{25}$ or by the judgments of his conscience. ${ }^{26}$ The control over this individual exercised by his conscience or the frustrating person renders him powerless to express overtly

17. MENNINGER 39.

18. Ibid.; New Reasons for Suicide, 74 Current Opinion 728 (1923).

19. Fenichei, The Psychoanalytic Theory of Neurosis 390-91 (1945) (hereinafter cited as FENICHEL); MENNINGER 45-47.

20. DuRkHEIM, SUICIDE 243 (1951).

21. In other societies, under certain circumstances, suicide may be socially approved or even required. See 2 WESTERMARCK, THE ORIGIN AND DEVELOPMENT OF Moral IDEAs c. 35 (1906); DuRkheim, SuIcIde 219 (1951). See also State v. Coudotte, 7 N.D. 109, 72 N.W. 913 (1897); Zilboorg, Differential Diagnostic Types of Sticide, 75 ARCh. NEUROL. \& PsYCH. 270 (1936).

22. Clinical experience indicates that the majority of suicides are of the type described. BRILL, FundaMenNTAL ConcepPTs of PSychoanalysis 262 (1921); Bergler, Suicide: Psychoanalytic and Medicolegal Aspects, 8 LA. L. REv. 504, 622 (1948); Lonsdorf, The Psychodynamics of Suicide, in Levin, Evidence and THE BEHAvioral SCIENCES C-7, C-8 (mimeo. 1956). Other types are possible. See, e.g., the descriptions in Mennrnger 47; Lewis, Studies on Suicides, 21 Psycr. Rev. 146-49 (1934).

23. "Clinical observation has established the fact that such individuals are emotionally or psychologically immature in that they have never graduated completely from the infantile modes of love and being loved." MENNINGER 39. See also note 7 supra.

24. FENTCHEL 387; MENNINGER 39-46.

25. Cf. FENTCHEL 387.

26. The conscience is viewed as having developed through the individual's childhood identification with his parents' attitudes, opinions and judgments. AlEXANDER, FundaMentals of PsychonNalysis 85 (1948). In a suicidally-inclined individual there appears to be an enormous over-development of the conscience with consequently inexorable and inflexible demands on him. MENNINGER 52. 
his rage against that person, ${ }^{27}$ and he instead turns it against himself. ${ }^{28}$ Experience has taught us that when a person is full of rage and is unable to vent it on others, he often takes it out on himself, ${ }^{29}$. but the suicidal patient may actually report, "I am bad because I am a murderer," when he wants to say, "I am angry with $X$; he has treated me as if he wanted to murder me." 30 As a result, following a threat to his self-esteem, such a person instead of feeling that he is hated tends to feel that he is not hated as much as he should be, and that his reasons for so judging himself are not sufficiently apparent to others. ${ }^{31}$ Thus, not rage, but a guilt feeling is experienced.

In acting suicidally this individual not only turns against himself a violent reaction to frustration, but also attempts, consciously or unconsciously, to control his environment by stimulating sympathy and guilt feelings in other people. ${ }^{32}$ This element is most apparent in unsuccessful suicide attempts, ${ }^{33}$ but even in these the self-destructive elements are apparent and the question may legitimately be asked why these individuals could find no better way to control environment than through an act of self-destruction. The aggressive hostility and underlying guilt seem to be the answers.

The feelings of guilt are not usually involved with obvious immediately preceding events, although these events may, by threatening self-esteem, increase hostility and guilt and so lead to the suicide attempt. ${ }^{34}$ It therefore becomes less difficult to explain both the apparent inadequacy and the myriad kinds of the events which have precipitated suicide. ${ }^{35}$

27. MENNINGER 37-38. Thwarting in the implementation of direct aggression may also be the result of weakening from the admixture of erotic elements. This simply means that we find it exceedingly difficult to kill someone we love. See FENICHEL 39697.

28. Ibid. The turning against the ego was discovered by Freud in analyzing the self-reproaches of depressed patients. 4 Freud, Collected Papers c. 8 (1924). Apparently meaningless self-reproachful statements proved to have meaning if the name of the hated object was substituted for "I." The self-reproaches were originally reproaches against the object. The bad characteristics of an object which one dares not become aware of because one fears the hatred they would arouse are perceived in one's own self instead. The depressed patient says, "I am bad because I am a liar" when he wants to say, "I am angry with X because he has lied to me"; or "I am bad because I am a murderer" when he wants to say, "I am angry with $X$; he has treated me badly as if he wanted to murder me."

29. SaUt, EMotional Maturiry c. 11 (1947).

30. See note 28 supra.

31. FENICEEI 392, 397-98.

32. LeVin, EVIDENCE, AND THE BeHavioral Sciences C-8 (mimeo. 1956).

33. Attempts and even insincere gestures at suicide are generally regarded as involving the same psychodynamics as the successful act. Fisch, The Suicidal Gesture: A Study of 114 Military Patients Hospitalized Becantse of Abortive Suicide Attempts, 111 Am. J. Psych. 33, 36 (1954). It has been hypothesized that attempts and insincere suicide gestures are related to suicide, but that aggression in these cases has not been internalized to the same extent. Ibid. Menninger regards them as similar but has a different hypothesis to explain dissimilarities. MENNINGER 72 .

34 . See text at note 32 supra.

35. Success, for example, may to some individuals appear as an imposition of further tasks to be fulfilled, and thus intensifies his awareness of his inferiority and his need for support for his self esteem. This frustration increases aggressive and guilt feelings. See FENICEEI 390-91. For another explanation of the same phenomenon, see MENNINGER 45-47. 
Out of the multitude of events capable of prompting suicide attempts in almost all ${ }^{36}$ cases in which evidence of such an attempt was admitted, the courts could have been certain of only one potential causal event-the jailing of the accused-yet jailing was never so much as considered as a possible cause. Jailing was ignored notwithstanding that the Coudotte case had previously excluded the evidence, where it was offered to corroborate the testimony of confessed accomplices, because the defendant was an Indian, a type known to react suicidally to confinement. It seems at least as clear, however, that jailing can represent to one who is suicidally inclined a loss of self-esteem and an increase in the need for regard from others, to the same extent as may ill health or sudden financial success. Therefore, such a person may resort to suicide upon being jailed, regardless of whether he committed the crime for which he is being held.

It would be perfectly consistent with psychoanalytic theory to suppose that some of those who attempt suicide in or out of jail do so because they committed the crime for which they are subsequently tried. ${ }^{37}$ Following a murder, for example, the murderer's rage, having been deprived by the homicide of the object of its gratification, may be turned by his conscience back upon himself and expressed in suicide. ${ }^{38}$ It is possible that psychoanalytic theory may even be said to confirm, in some instances, the judicial analogy between suicide and flight as an attempt to escape punishment, for suicide may in part result from a narcissistic desire to kill oneself instead of being executed by others. ${ }^{39}$ Nevertheless, in view of the myriad of other events which might have prompted the suicide attempt, there is no basis for assuming that an attempt tends to show that those who so act are more likely to be guilty than those who do not. Without such an affirmative showing, it is submitted that evidence of a suicide attempt should be excluded as irrelevant. ${ }^{40}$

On the basis of available knowledge of suicide, it would appear impossible, without psychiatric examination of the accused, ${ }^{41}$ for the state to negate all motives other than consciousness of guilt in order to qualify the evidence. However, in an exceptional case the prosecution may be able to so delimit the possible suicidal motives that the attempt does tend to add something to the likelihood that the defendant committed the act with which he is charged. State v. Plunkett ${ }^{42}$ suggests such an instance. In that case, the defendant was found bleeding profusely from a slashed wrist; his baby was discovered nearby, beaten to death. Remarks of the accused indicated that the death of the child-by whomever caused-had prompted his suicide attempt. Because the act of self-destruction was so

36. See notes 9 and 10 supra.

37. See note 44 infra.

38. MENNINGER 32.

39. Id. at 70 .

40. See text and citations at notes 12 and 13 supra.

41. $C f$. text at notes 16-35 supra.

42. 62 Nev, 258, 149 P.2d 101 (1944). 
clearly connected with the death of the child, the state had considerably narrowed the range of suicide motives. The death of a loved one, from whatever cause, appears to be a relatively frequent precipitant of suicide. ${ }^{43}$ However, no statistical data are available revealing what proportion of those who attempt suicide following the death of a loved one have themselves killed that loved one. ${ }^{44}$ Nevertheless, suicidal behavior under these circumstances does indicate that the actor's attitude toward the deceased was extremely ambivalent between love and hate. ${ }^{45}$ If the accused hated the deceased, the likelihood that he killed the deceased is advanced. ${ }^{46}$ Consequently, in this situation, assuming the validity of the psychological theories employed, evidence of a suicide attempt is probably relevant to legal guilt. ${ }^{47}$

Determining what weight this evidence should properly be given is a more difficult question. While common knowledge is usually available to determine the probative value to be accorded evidence of criminal motive, this source is not very helpful here. Moreover, expert knowledge appears inconclusive. On one hand, clinical experience indicates that although a person who commits suicide is driven by the motive to kill someone else, it is very rare that this motive results in his killing anyone but himself. ${ }^{48}$ Thus, the evidence may appear to deserve very little weight.

43. As indicated in text and citations at notes 23-25 supra, the characteristic object relationships of most suicidally-disposed types are ambivalent between love and hate. Mourning becomes pathological if the relationship between the mourner and the lost object was an extremely ambivalent one. As noted in notes 28 and 30 supra, identification with the hated object is characteristic of suicides, and has a punitive significance: "Because you have wished the other person to die, you have to die yourself." Moreover, narcissistically-oriented persons, in the painful state of mourning, tend unconsciously to reproach their dead friends for having brought them into this painful state. These reactions create guilt feelings and remorse. See FENICHEL 393-96.

44. Data are, however, available giving some indication of what proportion of those who kill loved ones thereafter commit suicide. See WolFGang, Patrerns IN CRIMINAI HonICIDE c. 15 (to be published by University of Pennsylvania Press 1957). Four out of every one hundred who commit criminal homicide kill themselves, according to a study conducted in Philadelphia. Ibid. In England, however, homicide-suicide cases comprise $22 \%$. Ibid. The Philadelphia study indicated that the chief criterion for differentiation between homicides followed by, and those not followed by, suicide was the degree of positive attachment between killer and victim. In 18 of 26 victim-offender relationships, the victim was a relative of the offender, and in another 7 , the victim was the offender's paramour. Of total homicides, however, relatives and paramours comprise only one-third of the victim offender relationships. Ibid. It also appears that homicides by homicide-suicides were proportionately more violent than homicides in general (violence being defined in terms of multiple killing injuries).

45. See note 43 supra.

46. It is well established that subsequent as well as prior evidences of hostility will be admitted to prove criminal acts committed against the hated object. See cases collected in 2 WIGMORE, EVDENCE $\$ \$ 395-97$ (3d ed. 1940) (hereinafter cited as WIGMSORE).

47. If consideration is given to the hypothetical nature of the theories employed, see note 7 supra, to demonstrate relevance, the evidence might reasonably be excluded as irrelevant when offered by the prosecution. Because of the courts' strong presumption of innocence in favor of the defense, $c f$. Demetree v. United States, 207 F.2d 892, 894 (5th Cir. 1953), psychiatric theories employed by the prosecution might be expected to encounter somewhat stricter scrutiny than the same theories when propounded by the accused.

48. Although the wish to kill may have been conscious, it will have been repressed, disguised by a conscious attitude of love, protection, obedience. When such feelings of 
On the other hand, this conclusion is justified only if the conduct of those who complete suicide is sufficiently similar to those who merely attempt to do so. However, a recent study of some people who were unsuccessful in their suicide attempts revealed that a significant proportion of this group was characterized by behavior overtly aggressive towards others. ${ }^{49}$ The study suggests that while suicide attempts involve psychological elements similar to those existent in completed suicides, the extent to which the aggression in the former instance has been turned against the actor is not equal to that involved in successful suicides.50 Although the attempt indicates that the accused has aggressive tendencies which may be directed against others, it cannot be concluded that all those who merely attempt suicide are more likely to have killed another than those who actually complete suicide. A suicide attempt in jail, for example, may be unsuccessful not because of psychological factors but because the most efficient means of self-destruction are not available to the inmate. Consequently, unless it is shown that the attempt was unsuccessful because of the lack of effective means to accomplish its objective, it would appear prejudicial to regard the defendant as psychologically different from one who completes suicide. Moreover, if the above showing is not forthcoming, in addition to denying added weight to the evidence of the attempt it also seems plausible to give it even less weight than that normally accorded the motive of hate, since the suicidal type will be more likely to respond to his motivations by directing his aggression towards himself rather than against others.

Because of the consistency of reported judicial rulings on the subject, ${ }^{51}$ in actual practice the burden is probably on the defense to justify exclusion of the evidence, rather than on the prosecution to justify its introduction. Nevertheless, since these opinions have evidenced no examination of the mechanisms of suicide attempts, ${ }^{52}$ in a proper case the defense, with the aid of a psychiatrist, may have a good chance to prevent admission of the evidence by acquainting the judge with the results of studies of suicide attempts generally which negate the relevance of attempts to the guilt of the accused. In addition, the psychiatrist may be able to offer an affirmative theory to explain the suicide attempt on some ground other than the accused's desire to escape deserved punishment. ${ }^{53}$ If the

hostility are not permitted to the person's conscience, the individual manifests not aggression but guilt feelings. See FreUd, Crvilizarion aNd Irs DisconTEN's c. 7 (1930); MENNINGER 57-58; text at notes 29-31 supra.

49. Of 114 attempted suicides hospitalized at the United States Naval Hospital, Philadelphia, during 1951, almost a fifth were guardhouse prisoners. Fisch, supra note 33 , at 36.

50. Ibid. See also discussion in note 33 supra.

51. See note 9 supra.

52. Notable exception: State v. Coudotte, 7 N.D. 109, 72 N.W. 913 (1897), discussing the cultural determinants of suicide among American Indians.

53. Psychiatric investigation is available to lawyers involved in cases in which suicide is a feature, at least in our larger metropolitan areas. It is estimated that four to ten hours, at twenty to twenty-five dollars per hour, would be necessary. LEVIN, EvIDENCE AND THE Behavioral Sciences C-35 (mimeo. 1956). Time for the doctor to travel to the hospital room or prison would probably be charged at the same rate. 
evidence cannot thereby be excluded, expert testimony might be employed to rebut the inference that the accused was so motivated, by showing alternative motives inferrable either from psychiatric knowledge of suicide generally or from an examination of the accused himself. ${ }^{54}$

\section{Admissibility in Prosecution for Homicide of Declarations by the Alleged Victiar Indicating Suicidal Disposition}

In prosecutions for homicide where the accused alleges that the deceased committed suicide, declarations or threats by the deceased indicating a suicidal disposition have generally been admitted as tending to show that his strbsequent death resulted from suicide. ${ }^{55}$ The assumption that threats tend to show suicide has some support in clinical findings. In studies conducted among patients undergoing psychiatric treatment, those expressing suicide thoughts were generally found not only much more severely disturbed than patients who had shown no suicidal tendencies but also much more disturbed than patients who had actually, but unsuccessfully, attempted suicide.56 Although the suicide rate among those who threaten suicide has not yet been effectively measured, ${ }^{57}$ these studies indicate that it is probably much greater than among non-threatening patients. ${ }^{58}$ If threats thus increase the likelihood of suicide among psychiatric patients, it is probable that threats have similar significance among non-patients. However, since clinical experience indicates that exceedingly few of those who threaten suicide actually commit it, ${ }^{59}$ the probative weight of this evidence is but slight.

Most courts which have admitted evidence of threats have also conditioned admissibility on a showing that: (1) the circumstances of death were as consistent with suicide as with homicide, and (2) the declarations were made within a reasonable time before death. ${ }^{60}$ In ruling on the first of these conditions, the courts have not always made clear the underlying assumptions upon which their decisions have rested. For example, in a recent Pennsylvania case, the court regarded the fact that the deceased

54. For the admissibility in homicide cases of suicide plans of the alleged victim, see pp. 399-402 infra, and of suicide motives of the alleged victim, see cases cited in 1 WIGMORE § 144 .

55. See cases cited in $1 \mathrm{id}$. $\$ 143$ n.1. Though hearsay, such statements are regarded as within the exception for design, plan or mental condition. 1 id. $\$ 79$.

56. Farberow, Personality Patterns of Suicidal Mental Hospital Patients, 42 GENETIC Psych. MoNograpHS 3, 79 (1950); Rosen, Hales \& Simon, Classification of "Suicidal" Patients, $18 \mathrm{~J}$. Consult. Psych. 359-62 (1954); cf. note 33 supra.

57. Rosen, Detection of Suicidal Patients: An Example of Some Limitations in the Prediction of Infrequent Events, 18 J. Consurt. PsycH. 397 (1954).

58. Note that the suicide rate for psychiatric patients is approximately .0033 , ibid.; for the population in general, .000099, U.S. BuREAU OF THE CENSUS, DEp'T of CoMMIERCE, Statistrcal Abstract of THE UNITED States 70 (1956); or a ratio of about thirty-three to one.

59. Rosen, supra note 57 , at 397-98.

60. E.g. Commonwealth v. Trefethen, 157 Mass. 180, 31 N.E. 961 (1892); Sutter v. State, 102 Neb. 321, 167 N.W. 66 (1918). 
landed head first after falling from a window as inconsistent with suicide. ${ }^{61}$ Apparently, the premise was that all such suicides hit the ground feet first. Such a view, however, ignores the fact that suicides have involved almost every conceivable method of self-destruction. ${ }^{62}$ Even if the court's premise had been indisputable, the justification for this requirement, if any, would depend on assumptions about facilitating an orderly trial procedure rather than on any interpretation of the psychology of suicide. A court which concedes that threats increase the probability of a subsequent suicide, and nevertheless excludes such evidence because the circumstances of death made suicide seem physically unfeasible, is assuming that the jury should not be burdened with relevant evidence when the fact which that evidence tends to show has been rendered unlikely by other evidence. It is submitted that, as Wigmore has suggested in his discussion of suicide threats, ${ }^{63}$ the function of balancing relevant facts against each other is normally assigned to the jury. Conforming to this theory, the admissibility of suicide threats should not be affected by other evidence relating to the probability that suicide accounted for the subsequent death. Evidence concerning improbability should be made a matter for rebuttal alone.

Where the second requirement-reasonable proximity in time-has been invoked for admissibility of suicide threats, the courts have not always agreed what constitutes a reasonable time. Six years was not too long for one court, ${ }^{64}$ although two weeks was too long for another. ${ }^{65}$ Whether the time interval should affect admissibility, and if so, what time lengths should be considered significant, depends almost entirely on assumptions about the nature and frequency of suicide. A court that would include a threat made two hours before death but exclude one made two weeks before, makes two assumptions which, if accurate, destroy the relevance of the latter declaration: first, that suicidal tendencies tend to diminish rather than increase with the passage of time; second, that such diminution is so marked that a person who threatens suicide two hours before his death is more likely to have committed suicide than one who has not so threatened or whose threat was made at an earlier time, whereas a person who threatens suicide two weeks before his death is no more likely to accomplish the act than one who has not made such threat.

61. Commonwealth v. Donough, $377 \mathrm{~Pa} .46,50,103$ A.2d 694, 696 (1954) ; cf. Lee v. Commonwealth, 312 Ky. 116, 226 S.W.2d 759 (1950) (death caused by strychnine poisoning; general finding that "the facts" do not indicate suicide in any way),

62. For a collection of bizarre methods, see Kennan, Problems of Suicide, $31 \mathrm{Mc}-$ Clure's Magazine, June 1908, pp. 218, 227 (e.g., self-cremation is comparatively common). Nevertheless some methods are much more frequent than others. E.g., a recent study found asphyxia $(34 \%)$ and firearms $(30 \%)$ the most frequent. Schmid \& Van Arsdal, Completed and Attempted Suicides: $A$ Comparative Analysis, 20 Am. Soc. REv. 273, 280-81 (1955).

63. 1 WIGMORE $\$ 143$.

64. Blackburn v. State, 23 Ohio St. 146 (1872) ; cf. People v. Conklin, 175 N.Y. 333, 67 N.E. 624 (1903) (three years); Bowie v. State, 185 Ark. 834, 49 S.W.2d 1049 (1932) (two months).

65. Commonwealth v. Donough, 377 Pa. 46, 103 A.2d 694 (1954). However, the court's ruling was probably based primarily on logical rather than temporal remoteness. See note 77 infra; $c f$. State v. Kelly, 77 Conn. 266, 58 Atl. 705 (1904) (one year). 
It is clear that suicidal tendencies do change with the passage of time. Suicide is the result of both external pressures on the individual and the internal resistance of which his personality is capable. ${ }^{86}$ Although an individual's predispositions to suicide may change under the impact of external events, ${ }^{67}$ the change is as likely to be toward suicide as away from it, ${ }^{68}$ depending on the nature of these events. Consequently, the suicide rate among those who threaten is not likely to be sufficiently changed by the passage of time to bring that rate below the rate for a comparable group of non-threateners. It is therefore submitted that the evidence ought to be admitted without regard to its remoteness. ${ }^{69}$ Of course, in an individual case, passage of time can be significant when related to intervening events which would have strengthened the deceased's ability to avoid selfdestruction. However, as was suggested above, evidence concerning the improbability of suicide should not preclude evidence of its probability, but should be restricted to rebuttal.

As a practical matter, defense counsel may have to contend with unfavorable judicial precedent as to what constitutes a reasonable time interval. ${ }^{70}$ However, these precedents are not insurmountable. First, they apparently were arrived at on the basis of common knowledge, and recent findings in the statistical and clinical disciplines justify some scepticism of such a foundation. For example, common knowledge, as expressed by the courts, considers those who attempt suicide as more likely to have subsequently done so than those who "merely" threaten suicide. ${ }^{71}$ Expert knowledge, as noted above, ${ }^{72}$ indicates the contrary. While this expert knowledge may not be entirely objectively verified, ${ }^{73}$ and deductions from it not entirely refined, ${ }^{74}$ some courts may regard the defendant in a criminal case as entitled to the benefit of the doubt in questions not only of burden of proof ${ }^{75}$ but also of relevance. ${ }^{76}$ Consequently, the time barrier might be overcome on the basis of general psychiatric theory.

Second, the courts have shown a willingness to regard longer periods as reasonable when a logical connection is shown between the circum-

66. See text and citations at notes 16-35 supra.

67. Cf., e.g., the demonstrated effect of business failure noted in DuBlin, THE FACrS OF LIFE 264-65 (1951).

68. Cf. FENICHEL 401 : "The factors, doubtlessly quantitative in nature, that determine whether or when the result [of depression] is to be a suicide, a maniac attack, or a recovery are still unknown."

69. Cf. the treatment given homicide threats, which are admissible against the accused without regard to the passage of time between the threat and the killing. 7 WIGMORE \& 108. weeks).

70. See, e.g., Commonwealth v. Donough, 377 Pa. 46, 103 A.2d 694 (1954) (two

71. See, e.g., Commonwealth v. Trefethen, 157 Mass. 180, 31 N.E. 961 (1892); cf.

Lee v. Commonwealth, 312 Ky. 116, 226 S.W.2d 759 (1950).

72. See note 56 supra.

73. See note 7 supra.

74. See text at notes 56-59 and 67-69 supra.

75. Cf., e.g., Demetree v. United States, 207 F.2d 892, 894 (5th Cir. 1953).

76. $C f$. note 47 supra. 
stances prompting the threat and those surrounding the subsequent suicide. ${ }^{77}$ To a skilled observer most suicides can be seen to have manifested their intention well before death. ${ }^{78}$ Therefore, with the aid of a psychiatrist, evidence of the deceased's behavior may be uncovered from which some theory can be developed to establish the likelihood that his death resulted from suicide, and to locate the immediate and long-range reasons for his self-destruction. Facts tending to show a theory of suicide appear to be admissible, the courts having admitted, for example, the pregnancy of a single woman ${ }^{79}$ and exhibitions of melancholy. ${ }^{80}$ Moreover, in those jurisdictions where the defendant bears the risk of nonpersuasion in establishing suicide, ${ }^{81}$ it becomes imperative for some theory of suicide to be developed, since the weight properly attributable to threats by themselves would not be sufficient to affirmatively establish suicide.

\section{Admissibility of ThIRd-Party Suicide Notes as an Exception to THE Rule Against Hearsay}

Those who commit suicide frequently leave notes explaining the events which induced their self-destruction. On occasion these explanations may be relevant to the legal rights of others. For example, the deceased may admit in a note the theft of valuables and, in addition, exculpate someone else who had previously been accused of the theft, or inculpate another as an accomplice, or perhaps indicate a donee to whom the valuables may be traced. So far as these persons are concerned, the contents of the suicide note constitute hearsay evidence. Whether the evidence will nevertheless be admissible ${ }^{82}$ has been primarily a function of judicial treatment of those statements as possessing the same degree of reliability as legal precedent attributes to declarations which subject the declarant to criminal

77. Compare Commonwealth v. Santos, $275 \mathrm{~Pa} .515,119$ Atl. 596 (1923) (four weeks reasonable), with Commonwealth v. Donough, 377 Pa. 46, 103 A.2d 694 (1954) (two weeks unreasonable). The court in the latter case emphasized that the defense had shown no logical connection between the circumstances which prompted the threat (denial of $\mathrm{a}$ job) and the circumstances which allegedly prompted the suicide (suggestion by the accused that illicit intercourse be repeated).

78. Such observations would not, however, be conclusive. The low incidence of suicide has in itself been a major limitation in the development of an effective suicide detection device, for in the attempt to predict suicide, it has been found that a large number of false positives are obtained (people incorrectly classified as suicides). Rosen, supra note 57 , at 402 .

79. Commonwealth v. Trefethen, 157 Mass. 180, 31 N.E. 961 (1892).

80. Blackburn v. State, 23 Ohio St. 146 (1872) ; Boyd v. State, 82 Tenn. (14 Lea) 161 (1844).

81. For a discussion of the burden of proving the "defense" of suicide, as well as the hearsay problem presented by decedent's declaration, see 28 TEMr. L.Q. 143 (1954).

82. Statements made by a person not under oath nor subject to cross examination are labeled hearsay and inadmissible, if the relevancy of the statement depends on its veracity. 5 WIGMORE $\$ 1362$; UNIFORM RuLES OF EVIDENCE rules 62-63. But numerous well-defined exceptions admit certain hearsay statements which experience has shown more likely to be trustworthy because of the circumstances under which they are made. 5 Wigmore $\$ \S 1420-26$. Among these well-established exceptions is one that sanctions the admissibility of statements by third persons of facts which are adverse to their interest. 
or pecuniary liability.83 Very little consideration has been given to the fact that the declarant was about to commit suicide. Thus, the admissibility of third-party suicide notes has depended almost entirely on interpretation of the rules justifying admission of declarations against interest as an exception to the hearsay rule, ${ }^{84}$ and only by implication on any interpretation of the psychology of suicide.

The admissibility of statements adverse to the interests of the declarant is justified on the theory that experience indicates there exists a greater likelihood of trustworthiness in such statements than in some other forms of hearsay. ${ }^{85}$ Nevertheless, it is usually a prerequisite to admissibility that the declarant be unavailable and that the statement be against his pecuniary or proprietary interest. 86 In addition, it must be demonstrated that he was aware of this adverse effect and that he harbored no motive prompting a false statement. ${ }^{87}$ Although some advocate that penal liability should be considered as properly adverse along with pecuniary and proprietary interests, ${ }^{88}$ the majority of Anglo-American jurisdictions reject penal interest as insufficiently adverse to qualify as an exception to the hearsay rule. $^{89}$ Declarations against interest are admissible to prove not only the disserving fact but also other facts contained in statements collateral to the disserving statement.90 While some collateral statements are excluded, they are generally admissible when shown not to be self-serving. ${ }^{91}$

Suicide notes have been offered in evidence as declarations against interest in at least three situations. In the first, its introduction is sought by the accused as evidence that the deceased committed the offense for which the accused is charged. In Brennan $v$. State ${ }^{22}$ the court, finding the note to be against the suicide's penal interest, held it admissible. ${ }^{93}$ The court regarded the declaration's reliability as further guaranteed by the fact that the defendant was, at the least, but slightly known to the deceased, and, at the most, his enemy, so that there existed no motive to falsify in the defendant's favor. ${ }^{94}$

83. Brennan v. State, 151 Md. 265, 134 Atl. 148 (1926); Truelsch v. Miller, 186 Wisc. 239, 202 N.W. 352 (1925) ; Commonwealth v. Antonini, 165 Pa. Super. 501, 69 A.2d 436 (1949); $c f$. Scott County v. Fluke, 34 Iowa 317 (1872).

84. See cases cited at note 83 supra.

85. See note 82 supra.

86. See Jefferson, Declarations Against Interest: An Exception to the Hearsay Rule, 58 HARV. L. REv. 1 (1944) and cases cited therein.

87. Ibid.

88. See United States v. Donnelly, 228 U.S. 243, 277 (1913) (dissenting opinion); 5 WIGMORE $\S 1476$.

89. See Morgan, Declarations Against Interest in Texas, 10 TEXAS L. REv. 399, 409 (1932).

90. See Jefferson, supra note 86, at 59-62 and cases cited therein.

91. Ibid. See also, e.g., "neutral statements" in Turner v. Turner, $123 \mathrm{Ga} .5,50$ S.E. 969 (1905); Aetna Life Ins. Co. v. Strauch, 179 Okla. 617,67 P.2d 452 (1937).

92. 151 Md. 265, 134 Atl. 148 (1926) (conviction of bastardy reversed).

93. $C f$. Scott County v. Fluke, 34 Iowa 317 (1872), admitting the suicide's declarations to exculpate the defendant in a civil suit based on embezzlement where these declarations were not in a note but were made verbally in connection with suicide thoughts.

94. The court also emphasized that the note was found in the deceased's handwriting, and on his body. 
In the second situation, the note is offered by a plaintiff seeking to impose a constructive trust on the proceeds of a life insurance policy. The note, in this instance, indicates that the insured paid his premiums with money stolen from plaintiff. In Truelsch $v$. Miller ${ }^{95}$ the court supported admission of the note because the assertions were against the declarant's penal and pecuniary interests. Moreover, it was observed that even if the statements revealing the disposition of the stolen funds were regarded as collateral to the disserving statements about the thefts, the statements about disposition were not self-serving to the deceased.

In the third situation, the prosecution seeks to introduce a note wherein, in addition to the deceased's admission that he participated in the offense for which the accused is charged, the accused is named as an accomplice. Such a note was excluded in Commonwealth $v$. Antonini ${ }^{96}$ because the court refused to recognize penal interests as sufficiently adverse, and also because the inculpating collateral matter was regarded as acquiring no reliability from its connection with the disserving statements. ${ }^{97}$

With the possible exception of the Brennan case, ${ }^{88}$ none of these courts explicitly considered of any consequence declarant's suicidal intent when the notes were written. It appears to have been assumed that confessions of crime are as much against present interest as if the declarant suicide-to-be envisaged a normal future when he wrote the damaging words. This approach, however, is not peculiar to the suicide situation. The courts appear never to have attached any significance, in connection with declarations against interest, to the fact that declarant knew his death to be imminent.99

Psychiatric findings are not necessary to appreciate that assertions in suicide notes may not offer the same safeguards of the writer's sincerity as are normally assumed to exist in declarations against penal or pecuniary interests. When declarant knows that he will not be present to respond to prosecution or civil suit, impending liability cannot be considered a motivating impetus ensuring trustworthiness. Of course, some suicides arise from a mere gesture at self-destruction which, for reasons beyond the deceased's control, ${ }^{100}$ unexpectedly resulted in a "successful" attempt. In

95. 186 Wisc. 239, 202 N.W. 352 (1925).

96. $165 \mathrm{~Pa}$. Super. 501, 69 A.2d 436 (1949) (on appeal by Commonwealth, grant of new trial by lower court en banc following conviction for embezzlement affirmed).

97. The court's assertion that the collateral statements could not be admissible has been interpreted as creating a new category of collateral statements, based on some privilege which the court seemed to feel exists for defendants in criminal prosecutions in connection with the accusations of co-conspirators. See Note, 98 U. PA.' L. REV. 755 (1950).

98. The court in the Bremnan case, however, seems implicitly to have assumed that a suicide about to die will not lie about the cause of his death. "Of course, if the defendant fails at the retrial of the case to prove that the letter found on the deceased contained an admission of guilt and assigned this guilt as the reason for his rash act, then neither the fact of the suicide nor the verbal admissions of guilt by the deceased prior to his death would be admissible." $151 \mathrm{Md}$. at 272-73, 134 At1. at 151. (Emphasis added.)

99. See cases cited in Jefferson, supra note 86, at 55-56.

100. See text and citations at note 33 supra. 
such cases it would appear that the deceased actually contemplated surviving and being required to account for his misdeeds: However, these declarations, although against his interest, should not therefore be regarded as reliable. The aggressive drives of some who behave suicidally are as likely to lead them to falsely inculpate third persons as the guilt feelings of other suicidal types are likely to lead them to falsely exculpate others. ${ }^{101}$ These drives, by establishing a motive to falsify, preclude such notes from complying with a necessary prerequisite for admissibility of declarations against interest. ${ }^{102}$

It has been suggested that even though suicide notes do not qualify as declarations against interest according to the recognized rules, admission of such evidence might nevertheless be justified by the reliability derived through the declaration's adverse effect on the pecuniary interest of the declarant's family. ${ }^{103}$ The assumption is that a suicide is unlikely to make false statements which are apt to result in unfounded claims against his estate and thereby lessen the amount of his property to be enjoyed by his family on his death. While this assumption may be applicable to "reasonable men," there is no certainty that it accurately reflects the conduct of suicidal types. It is true that most suicides are regarded psychiatrically as in part developing from an individual's effort to appease a tyrannical conscience, which might demand that he protect the interests of his family. ${ }^{104}$ However, the suicidal personality involves also an aggressive element which need not be completely internalized and may in fact be directed against the actor's family through a suicide note which will cause them a pecuniary as well as an emotional loss at his passing. ${ }^{105}$ Another theory of admission which may be advanced is that the deceased's interest in his good name and reputation guarantees reliability to any suicide notes disparaging his reputation. Here too is a proposition which may be generally sound but inapplicable to suicides, since such persons characteristically engage in exaggerated or groundless self-depreciation. ${ }^{108}$ Finally, it might be urged that the evidence could be admitted by considering suicide notes reliable for the same reasons as are dying declarations. ${ }^{107}$ The assumption here is that one aware of impending death will not lie, at least not about the reason for his death. Whatever may be the

101. See note 22 supra.

102. See text at note 87 supra.

103. Cf. Jefferson, supra note 86 , at 57 .

104. See text at notes 26 and 27 supra. See also FENICHEL 400.

105. Ibid.; see text at note 32 supra. See also the suicidal fantasies of neurotically depressed children, the love-blackmailing tendency of which is obvious: "When I am dead the parents will regret what they have done to me and will love me again." Bender \& Schilder, Suicidal Preoccupations and Attempts in Children, 7 AM. J. ORTHOPSYCH. 225 (1937).

106. See notes 28 and 30 supra.

107. Declarations of one who is conscious of impending death and who subsequently dies are admitted in homicide cases insofar as they relate to the circumstances of the killing and to the events more or less nearly preceding it in time and leading up to it. See cases cited in McCormick $\$ \S 259-60$. 
usual validity of that assumption, it seems inapplicable to suicides in view of their characteristic aggressive and guilt feelings.

Thus, it appears reasonable to conclude that whether or not a suicide note can be formally characterized as a declaration against either pecuniary or penal interests, such a note cannot be regarded as of general trustworthiness. The sharp categories in which the courts have defined the special situations in which hearsay proof should be allowed are said to be based in part on the particular reliability of declarations made in these situations. ${ }^{108}$ Moreover, even those reform authorities who would by-pass these categories have continued to require reliability, in that admissibility is made to depend on a finding that the declaration was made in good faith. ${ }^{109}$ Consequently, to be consistent with either approach third-party suicide notes should be excluded.

\section{Suicide and Sanity for the Purpose of Determining Rights Under WorkMEN's COMPENSATion Statutes}

Numerous cases in the workmen's compensation field have involved death claims by the survivor of an employee who committed suicide allegedly as the result of an accidental physical injury incurred in the course of his employment. ${ }^{110}$ Not all of these self-inflicted deaths have been held compensable, however. Even though the accidental injury was acknowledged to be the event that actually triggered the suicide, several doctrinal approaches have been successfully employed in resisting these claims. The most frequent has been reliance on the provisions of forty-one state statutes ${ }^{111}$ which exclude from coverage "intentional" self-injury. ${ }^{112}$ Recovery has also been denied on the theory that suicide is an independent intervening cause, obviating the accidental physical injury as the proximate cause of death. ${ }^{113}$ With each of these approaches denial of compensation

108. See note 82 supra.

109. See, e.g., Mass. Acts 1898, c. 535; UNIForm Rules of Evidence rule $63(4)$ (c). But cf. MCCormICK 627 , suggesting that as a precondition to admissibility only the unavailability of the declarant and the accuracy of the declaration's transmission be required.

110. See cases cited at notes 110-22 infra. Note that, as in other connections, a pre-existing weakness in the form of neurotic tendency does not lessen the compensability of an injury which precipitates a disabling neurosis. E.g., Farran v. Curtis Publishing Co., $276 \mathrm{~Pa}$. 553, 120 Atl. 544 (1923) ; Jacobson v. Department of Labor and Industries, 37 Wash. 2d 444, 224 P.2d 338 (1950).

111. The state statutes which make no specific reference to suicide or intentional self-injury are those of Connecticut, Illinois, Michigan, Montana, Nebraska, New Hampshire and Wyoming.

112. See, e.g., Kasman v. Hillman Coal \& Coke Co., 149 Pa. Super. 263, 27 A.2d 762 (1942); Industrial Comm'n v. Brubaker, 129 Ohio St. 617, 196 N.E. 409 (1935).

There is also statutory basis for the argument that workmen's compensation benefits extend only to "accidental" injuries, whereas suicide is intentional. The requirement that the injury be accidental in character has been adopted either legislatively or judicially by all but four states: California, Iowa, Massachusetts and Rhode Island. Rhode Island deleted the requirement by R.I. LAws 1949, c. 2282. 1 LARSON, WORKMEN's ComPENSATION 511 n.1 (1952).

113. See, e.g., Sponatski's Case, 220 Mass. 526, 108 N.E. 466 (1915) ; Barber v. Industrial Comm'n, 241 Wis. 462, 6 N.W.2d 199 (1942). 
for the suicide of an injured workman would seem to depend upon whether the act should be considered "intentional."

Most American decisions have purported to employ two tests, or variations thereof, to determine whether the self-destructive act at issue was intended. ${ }^{114}$ Death is said to be compensable when the suicide is either (1) the product of a delusion or otherwise without the deceased's knowledge of the physical consequences of his act; or (2) the result of an uncontrollable impulse, or otherwise without volition. ${ }^{115}$ Although the cases are purportedly so decided, and thus theoretically should be classifiable as compensable only if the employee killed himself under either of the above circumstances and as non-compensable if the employee knew what he was doing and was able to consciously control his behavior, in fact, however, a different pattern of decision emerges from the cases. The compensable cases are frequently marked by a particularly exhibitionist or eccentric method of self-destruction, while the non-compensable cases usually involve a quiet melancholy leading to a solitary and undramatic death. ${ }^{116}$ For example, the courts have permitted recovery without substantial evidence of defects either of the will or of the intellect where the deceased, during hospitalization for physical injury, silently leaped from a window in the presence of his nurse;117 where he became enraged at a trivial slight, assaulted his step-daughter, and then rushed out and hanged himself; ${ }^{118}$ and where he stubbornly starved himself to death. ${ }^{118}$ With similar evidence of volition and cognition, compensation was denied where the deceased wrote four eloquent suicide notes before shooting himself ; ${ }^{120}$ where he traveled to Canada and committed suicide in a lonely hotel room; ${ }^{121}$ and where he waited until his family had gone to Sunday school before committing the act. ${ }^{122}$

114. But cf. New York cases discussed at note 115 infra.

115. The formula most often found is that of Sponatski's Case, 220 Mass. 526, 530, 108 N.E. 466, 468 (1915) : Compensation for death will be made "where there follows as the direct result of a physical injury an insanity of such violence as to cause the victim to take his own life through an uncontrollable impulse or in a delirium of frenzy, without conscious volition to produce death, having knowledge of the physical .. . consequences of the act. .. " See also, e.g., Widdis v. Collingdale Millwork Co., 169

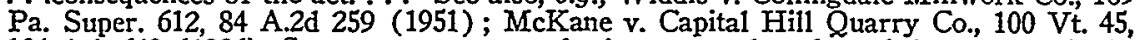
134 Atl. 640 (1926). Some courts may emphasize one or the other of the two standards. Compare Kazazian v. Segan, 14 N.J. Misc. 78, 182 At1. 351 (Dep't of Lab. \& Workmen's Comp. 1936), with McFarland v. Department of Labor and Industries, 188 Wash. 357, 62 P.2d 714 (1936). But cf. the courts of New York which in recent cases appear to have supplemented these standards with a condition that the suicide shall have been caused by a mental disease. Maricle v. Glazier, 283 App. Div. 402, 128 N.Y.S.2d 148 (3d Dep't 1954) ; Pushkarowitz v. A. \& M. Kramer, 275 App. Div. 875, 88 N.Y.S.2d 885 (3d Dep't 1949), aff'd, 300 N.Y. 637, 90 N.E.2d 494 (1950). The New York approach would thus seem to correspond closely to the English requirements. See, e.g., Withers v. London, Brighton \& S. Coast Ry., [1916] 2 K.B. 772.

116. Larson, Workmen's CoMpensation 505 (1952) and cases cited at notes 117 21 infra.

117. Gasperin v. Consolidated Coal Co., $293 \mathrm{~Pa} .589,143$ At1. 187 (1928).

118. McFarland v. Department of Labor and Industries, 188 Wash. 357, 62 P.2d

714 (1936).

119. Sinclair's Case, 248 Mass. 414, 143 N.E. 330 (1924).

120. Widdis v. Collingdale Millwork Co., $169 \mathrm{~Pa}$. Super. 612,84 A.2d 259 (1951).

121. Barber v. Industrial Comm'n, 241 Wis. 462,6 N.W.2d 199 (1942).

122. Industrial Comm'n v. Brubaker, 129 Ohio St. 617, 196 N.E. 409 (1935). 
It seems improbable that the disparity between the test's statement and its application is due to judicial unfamiliarity with the concepts employed, since comparable formulae control similar questions in insurance and criminal law. ${ }^{123}$ Moreover, the issue posed by the first test, whether deceased knew the physical consequences of his act, is one of fact which can be readily determined. Analysis of the deceased's conduct prior to his death, by laymen as well as by experts, can establish with reasonable certainty whether the individual was substantially disoriented from reality. Administration of the irresistible impulse test, however, is of greater difficulty. Whether there are impulses and unconscious drives that overwhelm some individuals is not the problem; most psychiatrists would readily admit that they exist. ${ }^{124}$ The real difficulty is in drawing the fine line distinguishing individuals whose actions are thus controlled from those whose are not. ${ }^{125}$ Even if the actor were available for analysis, an accurate performance of this task would be exceedingly difficult; in his absence, it would appear virtually impossible. ${ }^{128}$ With the burden of proof on the plaintiff to show accidental injury, if the traditional test were literally followed there would be virtually no instances of compensation where death was allegedly the product of an irresistible impulse.

It may be supposed that the response of the courts in sometimes allowing compensation in cases involving bizarre conduct preceding suicide, without more than the slightest suggestion of cognitive or volitional impairment, represents a rudimentary sense of justice which requires the employer to pay for his worker's eventual suicide when the worker was driven "crazy," though not otherwise. Indeed, the New York courts in recent cases have explicitly supplemented the traditional standards with the rule that the compensation will be granted when the suicide was the product of a "psychosis." 127 But this may not be helpful, for in many instances the psychosis cannot be affirmatively established without direct examination of the individual, ${ }^{128}$ a method which is precluded in suicide cases. In any event, the difficulty with a standard, implicit or explicit,

123. In a minority of jurisdictions, in suits to recover on accident and life insurance policies it has been held that the standard exclusion of suicide, "sane or insane," does not exclude self-inflicted death without cognition, because such death is indistinguishable from accidental death, which is covered. See 1 AppLEMAN, INSURANCE $\$ 363 \mathrm{n} .38$ (1941). Following the rule in the M'Naughton case, $10 \mathrm{Cl}$. \& Fin. 200, 210 (H.L. 1843), the same standards are used to determine criminal responsibility, except in the District of Columbia, Durham v. United States, 214 F.2d 862 (D.C. Cir. 1954); New Hampshire, State v. Pike, 49 N.H. 399 (1869) and possibly New Mexico, State v. White, 58 N.M. 324, 270 P.2d 727 (1954).

124. In a poll of members of the Group for the Advancement of Psychiatry on this question, ninety per cent answered in the affirmative. Guttmacher, Principal Difficulties With the Present Criteria of Responsibility and Possible Alterations, MODEL Penal Code 170, 174 (Tent. Draft No. 4, 1955).

125. Ibid.

126. Cf. ibid.

127. See note 115 supra.

128. The chief difference, medically, between neurosis and psychosis is the extent to which the individual loses ability to test reality, i.e., to perceive, integrate and realistically act upon events taking place in the world. ENGLISH \& FINCE, INTRODUC- 
which depends on whether the worker was "crazy" is that virtually all suicidal individuals in our society are probably severely disturbed.129

If some courts have felt compelled to expand workmen's compensation coverage beyond the strict limits of unintentional self-destruction, then the source of the disparity between some findings and any consistent standard related to mental health becomes clear. Caught between a statutory term ${ }^{130}$ which would almost always deny compensation and a sense of justice which would almost always require compensation, in reconciling these influences some judges and arbitration boards will favor one course, some the other. If this supposition is true, theoretically inconsistent decisions in suicide compensation proceedings may be expected to continue until the statutes are amended to include or to exclude all suicides, sane or insane.

However, any proposal to include all suicides would have to overcome the objection that giving compensation for self-inflicted injuries may encourage such injuries. Psychiatric theory would seem to indicate that in some cases knowledge that dependent survivors would be cared for might operate as one of the complex of factors inducing suicide. ${ }^{131}$ However, actual encouragement represented by the possibility of compensation is probably not significant. Because of the suicide's unconscious hostility toward his loved ones, in as many cases as it operates as an inducement, it probably has a deterrent effect. ${ }^{132}$ Moreover, the prospect of compensation is but one of a variety of factors influencing the suicide ${ }^{133}$ so that the possibility of suicide is not likely to be affected by awarding or denying compensation, whereas both the accident in the course of employment and the basic social need which prompted the enactment of these benefits continue to exist.

\section{Conclusion}

Judicial assumptions about suicide developed at a time when expert knowledge of the subject was more limited than at present. Moreover, the courts' interpretations of suicide were only rarely founded on a considered application of that knowledge which was then current. Notwithstanding advances in expert understanding, recent cases have, through adherence to precedent, preserved the older assumptions. Yet, between

tion to Psychiatry $43-44$ (1950) ; $c f$. Alexander, Fundangentals of PsychoanalYSIS 18-20 (1948). However, it is clear that in some individuals significant mistaken perceptions and interpretations need not always have been unequivocably manifested to observers.

129. See text and citations at notes 21-33 supra.

130. The proximate cause defense is avoided more simply than the statutory one. If the second cause is a natural and foreseeable consequence of the first cause, it has been argued that the second cause, the suicide, is not an independent intervening force. See Barber v. Industrial Comm'n, 241 Wis. 462, 467, 6 N.W.2d 199, 202 (1942) (dissenting opinion).

131. See text at note 104 supra.

132. See text at note 105 supra.

133. See text and citations at notes 21-33 supra. 
these assumptions and socio-psychiatric views there would appear to be the following areas of substantial divergence:

(1) The suicide attempt of an accused between the time of his alleged crime and his trial has uniformly been admitted against him on the theory that it shows deserved remorse or a desire to escape deserved. punishment. Expert knowledge, on the contrary, indicates that, in view of the great variety and apparent inadequacy of the circumstances capable of prompting suicidal behavior, evidence of attempts is not relevant to legal guilt.

(2) Courts assume that suicide thoughts or threats tend to show that the cause of the threatener's subsequent death was suicide. The learned literature tends to confirm the relevancy of threats, though it indicates that they are entitled to very little weight. Courts have also assumed that suicidal tendencies tend to diminish with the passage of time, so that the admissibility of threats should be conditioned on proximity to the time of death. However, expert understanding suggests that changes in an individual's predispositions to suicide are as likely to be toward it as away from it, depending on intervening events. Consequently, the evidence should be admitted without regard to time.

(3) The contents of suicide notes have sometimes been admitted, on the basis of rules justifying admission of declarations against interest as exceptions to the rule against hearsay, without explicit consideration of the effective suicidal intent of the declarant. However, expert knowledge indicates that not only do such notes not satisfy the formal requirements of these rules, but also that they are likely to be unreliable. Consequently, such declarations should not be admissible.

(4) In ruling on workmen's compensation claims based on suicide, many courts appear to have been reluctant to confine themselves to the strict statutory standard of "intention," but have granted compensation on a showing of dramatically abnormal behavior. Expert findings indicate that any implicit standard based on whether the worker was driven "crazy" is unworkable, since virtually all suicides in our society are probably severely disturbed. Consequently, conflicting results may be anticipated until the statutes expressly include or exclude all suicides, sane or insane.

M. M. D. 